\title{
PERLINDUNGAN EKSPRESI BUDAYA TRADISIONAL INDONESIA DALAM SISTEM YANG SUI GENERIS
}

\author{
Yenny Eta Widyanti \\ Fakultas Hukum Universitas Brawijaya \\ Jl. MT. Haryono 169 Malang 65142 Tlp. (0341) 553898 Fax (0341)566505 \\ Email : hukum.ub.ac.id ; yenni.eta@ub.ac.id
}

\begin{abstract}
This paper aims to analyze the importance of Indonesian traditional cultural expressions governed by sui generis. To obtain these objectives, this legal research uses statutory approach with a systematic interpretation. Based on the results, it can be concluded that the regulation of Indonesian traditional cultural expression in Law Number 28 of 2014 about Copyright still cannot realize the protection of Traditional Cultural Expressions due to differences in characteristic between copyright with traditional cultural expression.
\end{abstract}

Key words: Protection, Indonesian Traditional Cultural Expressions, Sui Generis

\begin{abstract}
Abstrak
Tulisan ini bertujuan untuk menganalisis pentingnya ekspresi budaya tradisional Indonesia diatur secara sui generis. Untuk memperoleh tujuan tersebut, penelitian hukum ini menggunakan pendekatan peraturan perundang-undangan dengan penafsiran sistematis. Berdasarkan hasil pembahasan maka dapat disimpulkan bahwa pengaturan ekspresi budaya tradisional Indonesia dalam Undang-undang Nomor 28 Tahun 2014 tentang Hak Cipta masih belum dapat mewujudkan perlindungan terhadap Ekspresi Budaya Tradisional karena adanya perbedaan karakteristik antara hak cipta dengan ekspresi budaya tradisional.
\end{abstract}

Kata kunci: Perlindungan, Ekspresi Budaya Tradisional Indonesia, Sui Generis 


\section{Latar Belakang}

Perlindungan ekspresi budaya tradisional dalam hak kekayaan intelektual hingga saat ini $^{1}$ masih menjadi perdebatan antara negaranegara maju (developed countries) dengan negara-negara berkembang (developing countries) dalam mewujudkan legislasi internasional. Hal ini terjadi karena ekspresi budaya tradisional memiliki nilai ekonomi, nilai sosial dan nilai budaya yang sangat besar sebagai bentuk warisan budaya bangsa.

Dalam perkembangannya, ekspresi budaya tradisional yang merupakan kekayaan warisan budaya yang bernilai tinggi tersebut kenyataannya telah menjadi daya tarik untuk dimanfaatkan secara komersial sehingga terjadilah penyalahgunaan (misuse) ${ }^{2}$, misapropriasi (misappropriation) ${ }^{3}$, perusakan nilai kebudayaan, serta eksploitasi oleh pihak asing. Dalam hal ini, kekayaan intelektual berupa ekspresi budaya tradisional yang diciptakan dan berasal dari masyarakat tradisional ${ }^{4}$ telah menjadi populer di seluruh dunia, kemudian diperdagangkan secara internasional bernilai sampai miliaran US Dolar setiap tahun dari seluruh dunia. Kebanyakan pendapatan dari penjualan ini akhirnya berada di tangan perusahaanperusahaan luar daerah asal kekayaan intelektual tersebut dan lebih sering di tangan perusahaan asing. ${ }^{5}$

1 Istilah Ekspresi Budaya Tradisional yang terdapat dalam Undang-undang No. 28 Tahun 2014 tentang Hak Cipta berasal dari istilah Traditional Cultural Expression yang terdapat dalam draft IGC-WIPO atau istilah Expressions of folklore yang terdaoat dalam Model Provision dengan ruang lingkup yang meliputi: productions consisting of characteristic elements of the traditional artistic heritage developed and maintained by a community of [name of the country] or by individuals reflecting the traditional artistic expectations of such a community, in particular: (i) verbal expressions, such as folk tales, folk poetry and riddles; (ii) musical expressions, such as folk songs and instrumental music; (iii) expressions by actions, such as folk dances, plays and artistic forms or rituals; whether or not reduced to a material form; and (iv) tangible expressions, such as: (a) productions of folk art, in particular, drawings, paintings, carvings, sculptures, pottery, terracotta, mosaic, woodwork, metalware, jewellery, basket weaving, needlework, textiles, carpets, costumes; (b) musical instruments; (c) [architectural forms]. Lihat Kuek Chee Ying, Protection of Expressions of Folklore/ Traditional Cultural Expressions: To What Extent is Copyright Law the Solution?, Journal of Malaysian and Comparative Law, 3/17/2011, p. 2 diakses 5 Februari 2020. Istilah lain dalam Tunis Model Law dikenal juga dengan istilah folklore, lihat Christoph Antons, "What is "Traditional Cultural Expression?", International Definitions And Their Application in Developing Asia”, W.I.P.O.J. 2009, 1(1), 103-116, WIPO Journal, 2009, p. 109. diakses 17 Februari 2020.

2 Menurut Black's Law Dictionary konsep penyalahgunaan (misuse) adalah penggunaan secara tak pantas, dalam suatu cara yang tidak sengaja atau tidak dapat dibayangkan, beberapa kamus hukum biasanya mendefinisikan misuse sebagai suatu penggunaan yang salah, tidak tepat, atau penerapan yang salah. Misuse bisa juga merujuk pada penggunaan yang melampaui batas kewajaran, atau bertindak mengubah tujuan asli atau mengubah fungsi dari sesuatu. Lebih lanjut baca dalam Diah Imaningrum Susanti dkk, Ekspresi Budaya Tradisional dan Hak Kekayaan Intelektual, (Malang: Dioma, 2019), hlm. 33.

3 Dibidang hukum kekayaan intelektual, Black's Law Dictionary mendefinisikan misapropriation sebagai perbuatan melanggar hukum dengan menggunakan informasi yang tidak dapat di- hakciptakan, atau menggunakan ide yang dikumpulkan dan disebarkan organisasi untuk keuntungan berkompetisi secara tidak wajar terhadap organisasi tersebut, atau memperbanyak suatu karya yang penciptanya belum ada atau diberi hak eksklusif atas karya itu. Baca dalam Diah Imaningrum, ibid, hlm. 34.

4 Masyarakat tradisional dalam tulisan ini meliputi pengertian indigenous people dan local communities, yaitu kelompok yang diidentifikasikan dengan penduduk asli suatu wilayah tertentu.

5 Badan Penelitian dan Pengembangan HAM Kementerian Hukum dan HAM RI, Perlindungan Kekayaan Intelektual Atas Pengetahuan Tradsional dan Ekspresi Budaya Tradisional Masyarakat Adat, (Bandung: Alumni, 2013), hlm. 3. 
Fakta tersebut menimbulkan berbagai isu strategis yang berujung pada kepentingan negara-negara berkembang, termasuk Indonesia. Kasus penyalahgunaan ekspresi budaya tradisional Indonesia oleh pihak asing yang pernah terjadi adalah klaim ekspresi budaya tradisional Indonesia oleh Malaysia, dimana dalam sebuah iklan di Discovery Channel dalam Enigmatic Malaysia, ditayangkan tari Pendet, Wayang, dan Reog Ponorogo dalam iklan pariwisata Malaysia. ${ }^{6}$ Kemudian kasus ekspresi budaya tradisional yang lain adalah pendaftaran motif batu kali kerajinan perak asal Bali oleh John Hardy International, Ltd. Pendaftaran motif batu kali tersebut menyebabkan perajin Bali, Ketut Deni Aryasa, tidak boleh menggunakan motif serupa yang telah lama dikenalnya sebagai motif kulit buaya. ${ }^{7}$ Kondisi ini menunjukkan bahwa perlindungan ekspresi budaya tradisional Indonesia dalam hukum hak cipta masih belum dapat diwujudkan, sebagaimana diperkuat oleh pernyataan Afifah Kusumadara bahwa "Copyright law did not have practical importance for Indonesia, as copyright law did not fit with Indonesian culture and level of development and was not consonant with the interest of Indonesians". ${ }^{8}$
Kejadian yang terjadi pada ekspresi budaya tradisional Indonesia juga dialami pada perlindungan ekspresi budaya tradisional Australia dalam sistem hukum hak kekayaan intelektual sebagaimana dinyatakan oleh Natalie Stoianoff dan Alpana Roy; ${ }^{9}$

Western intellectual property laws have developed over centuries to protect the cultural expressions, creativity and ingenuity of society. However, what is apparent from the four decades of investigation and discourse on Indigenous knowledge and culture in Australia is the inappropriateness of using Western intellectual property laws to protect the knowledge and culture of Aboriginal and Torres Strait Islander peoples living in Australia. The World Intellectual Property Organization ('WIPO') conducted its own analysis into the suitability of intellectual property laws to provide such protection to traditional or Indigenous knowledge and cultural expressions. This 'gap analysis' reinforced the importance

6 Ibid.,

7 Republika Online, <http://www.republika.co.id>, dalam Laina Rafianti dan Qoliqina Zolla Sabrina. "Perlindungan Bagi kustodian Ekspresi Budaya Tradisional Nadran Menurut Hukum Internasional dan Implementasinya dalam hukum Hak Kekayaan Intelektual di Indonesia” Padjajaran Jurnal Ilmu Hukum Vol. 1 No. 3, (2014): 500, diakses pada 1 Juni 2019.

8 Afifah Kusumadara, "Analysis of The Failure of The Implementation of Intellectual Property Laws in Indonesia", A dissertation submitted in fulfillment of the requirements for the degree of Doctor of Juridical Studies, (Sydney: Faculty of Law University of Sydney, 2000), tidak dipublikasi, p. 181

9 Natalie Stoianoff and Alpana Roy, "Indigenous Knowledge and Culture in Australia-The Case for Sui Generis Legislation”, Monash University Law Review 745, 2015. Monash University Law Review Vol 41, No 3:746, accessed 25 January 2017. 
of the work of the Intergovernmental Committee on Intellectual Property and Genetic Resources, Traditional Knowledge and Folklore ('Intergovernmental Committee') which was established in 2000 by the WIPO as a new division to cover Traditional Knowledge, Genetic Resources and Traditional Cultural Expressions/Folklore.

Dapat diartikan disini, bahwa hukum kekayaan intelektual yang dibangun oleh negara-negara barat lebih dari satu abad untuk melindungi ekspresi budaya tradisional, kreatifitas dan pengetahuan tradisional, pada kenyataannya berdasar investigasi selama empat dekade menunjukkan hukum kekayaan intelektual tidak tepat untuk melindungi pengetahuan dan budaya suku Aborigin dan masyarakat di Kepulauan Selat Torres yang tinggal di Australia. Hal ini dipertegas oleh pernyataan Terri Janke bahwa "Indigenous Australians continue to call for sui generis legislation to protect Aboriginal and Torres Strait Islander traditional knowledge and cultural expressions. They ask for recognition of their cultural rights within the Australian legal and policy framework". ${ }^{10}$

Lemahnya perlindungan EBT di Indonesia berbanding terbalik dengan besarnya jumlah EBT Indonesia. Kementerian Pendidikan dan Kebudayaan memiliki data yang menunjukkan bahwa hingga Tahun 2020 terdapat 9.770 (sembilan ribu tujuh ratus tujuh puluh) warisan budaya tak benda (intangible cultural heritage) Indonesia yang telah dilakukan pencatatan dan 1.086 (seribu delapan puluh enam) yang telah dilakukan penetapan. Karya budaya tak benda yang telah dikelola oleh Direktorat Jenderal Kebudayaan dan Direktorat Warisan dan Diplomasi Budaya Kementerian Pendidikan dan Kebudayaan tersebut, 12 (dua belas) diantaranya telah ditetapkan sebagai warisan dunia oleh UNESCO yaitu;

1. Pertunjukan Wayang (The Wayang Puppet Theatre),

2. Keris Indonesia (The Indonesian Kris),

3. Batik Indonesia (Indonesian Batik),

4. Pendidikan dan pelatihan batik Indonesia sebagai warisan budaya tak benda untuk pelajarSD, SMP, dan SMA(Educationand training in Indonesian Batik intangible cultural heritage for elementary, junior, senior, vocational school and polytechnic students, in collaboration with the batik museum Pekalongan),

5. Angklung Indonesia (Indonesian angklung),

6. Tari Saman (Saman Dance),

7. Tas Noken (Noken Multifunctional Knotted or Woven Bag, Handcraft of the people of Papua),

8. Tiga Genre Tari Tradisional di Bali (Three Genrees of Traditional Dance in Bali), 9. Pinisi, seni pembuatan kapal di Sulawesi

10 Terri Janke, Our Culture: Our Future - Report on Australian Indigenous Cultural and Intellectual Property Rights, (Sydney: Michael Frankel and Company, 1999), p. 112. 
Selatan (Pinisi, art of boatbuilding in South Sulawesi),

10. Pantun (Malay Oral Tradition),

11. Pencak Silat (Traditions of Pencak Silat),

12. Gamelan Indonesia (Indonesian Gamelan).

Menyikapi pentingnya perlindungan ekspresi budaya tradisional, hingga kini perundingan bidang ekspresi budaya tradisional di tingkat internasional sering dilakukan oleh World Intellectual Property Organization (untuk penulisan selanjutnya disingkat WIPO) sejak Tahun 2000 yang ditindaklanjuti dengan membentuk Intergovernmental Committee on Intellectual Property and Genetic Resources, Traditional Knowledge, and Folklorel Traditional Cultural Expressions (IGC GRTKF). Dalam hal ini, the Intergovernmental Commitee telah membangun model khusus atau rezim yang berdiri sendiri sebagai draft treaties untuk salah satu dari tiga bentuk subjek yang diatur, yang dinamakan a. Traditional Knowledge, b. Genetic Resources, dan c. Traditional Cultural Expression.

Berpijak pada fakta belum terwujudnya perlindungan ekspresi budaya tradisional Indonesia dalam hak cipta, maka permasalahan urgensi perlindungan ekspresi budaya tradisional Indonesia dalam sistem sui generis ${ }^{11}$ sangat penting untuk dilakukan. Untuk mendapatkan jawaban atas permasalahan tersebut digunakan metode penelitian hukum dengan pendekatan perundang-undangan (statute approach) terhadap Undang-undang Nomor 28 Tahun 2014 tentang Hak Cipta, RUU PTEBT, draft treaties IGC GRTKF, dan konvensi internasional terkait ekspresi budaya tradisional dengan menggunakan penafsiran sistematis, guna memenuhi hak-hak masyarakat tradional dalam mewujudkan keadilan dan kesejahteraan.

\section{Pembahasan}

\section{A. Pengaturan Ekspresi Budaya Tradisonal dalam Undang-undang Nomor 28 Tahun 2014 tentang Hak Cipta dan Rancangan Undang- undang Pengetahuan Tradisional dan Ekspresi Budaya Tradisional}

Undang-undang Nomor 28 Tahun 2014 tentang Hak Cipta (untuk penulisan selanjutnya disingkat UUHC) mengatur bahwa hak cipta adalah hak eksklusif pencipta yang timbul secara otomatis berdasarkan prinsip deklaratif setelah suatu ciptaan diwujudkan dalam bentuk nyata tanpa mengurangi pembatasan sesuai dengan ketentuan peraturan perundang-undangan. ${ }^{12}$ Terkait dengan hal tersebut maka Ciptaan adalah setiap hasil karya cipta di bidang ilmu/ pengetahuan, seni, dan sastra yang dihasilkan atas inspirasi, kemampuan, pikiran, imajinasi, kecekatan, keterampilan, atau keahlian yang diekspresikan dalam bentuk nyata. ${ }^{13}$

11 Dalam hal ini sistem sui generis dengan fokus eksplisit yang berisi HKI baru, atau hak seperti HKI, sering disebut sebagai perlindungan HKI sui generis.

12 Pasal 1 angka 1 Undang-undang Nomor 28 Tahun 2014 tentang Hak Cipta.

13 Pasal 1 angka 3 Undang-undang Nomor 28 Tahun 2014 tentang Hak Cipta. 
Selanjutnya Ciptaan ekspresi budaya tradisional dalam UUHC diatur dalam Pasal 38 ayat (1) yang menyatakan bahwa "Hak Cipta atas ekspresi budaya tradisional dipegang oleh Negara".14 Dalam hal ini Pasal 38 ayat (1) UUHC dapat dibandingkan dengan Pasal 3 Rancangan Undang-undang Pengetahuan Tradisional dan Ekspresi Budaya Tradisional (RUU PTEBT), yaitu “negara memegang kedaulatan untuk mengatur pengelolaan Pengetahuan Tradisional dan Ekspresi Budaya Tradisional untuk sebesar-besarnya kemakmuran dan kesejahteraan rakyat". Dapat diartikan disini bahwa, dalam UUHC maupun RUU PTEBT sama-sama mengatur bahwa ekspresi budaya tradisional dipegang negara. Negara adalah sebagai pengelola ekspresi budaya tradisional, sedangkan pemilik dan/ atau kustodian dari ekspresi budaya tradisonal adalah komunitas atau masyarakat tradisional yang menciptakan, memelihara, dan mengembangkan ekspresi budaya tradisional. Hal ini mengingat ekspresi budaya tradisional Indonesia pada umumnya tidak diketahui siapa penciptanya, dengan kesamaan rumpun yang multi-kultural. Hal ini sangat rentan terhadap pertikaian antar masyarakat tradisional atas kepemilikan ekspresi budaya tradisonal. Maka demi kepentingan bangsa dan negara agar terhindar dari disintegrasi bangsa, sudah sepatutnya pengelolaan atas ekspresi budaya tradisonal diserahkan kepada negara ditujukan sebesar-besarnya untuk kemakmuran dan kesejahteraan rakyat, dimana pada akhirnya ditujukan kepada masyarakat tradisional. Hal ini berkesesuaian dengan Pasal 16 ayat (1) RUU PTEBT yang menyatakan bahwa "Masyarakat pengemban menerima manfaat atas penggunaan Pengetahuan Tradisional dan Ekspresi Budaya Tradisional". Selanjutnya Pasal 16 ayat (2) RUU PTEBT lebih jelas memberikan kewenangan kepada pemerintah dan/ atau pemerintah daerah sebagai pengemban atas ekspresi budaya tradisional yang tidak diketahui masyarakat pengembannya untuk kepentingan bangsa Indonesia. Artinya, dibandingkan dengan UUHC maka RUU PTEBT lebih jelas dalam memberikan kewenangan kepada pemerintah dan/ atau pemerintah daerah dalam pengelolaan ekspresi budaya tradisional untuk mewujudkan kesejahteraan masyarakat tradisional pada khususnya dan rakyat Indonesia pada umumnya.

Selanjutnya ditinjau dari pemenuhan hak-hak masyarakat tradisional atas manfaat ekonomi ekspresi budaya tradisional yang tidak diatur dalam UUHC, maka dalam Pasal 18 RUU PTEBT lebih jelas dalam mengatur hal ini. Yaitu "Pembagian manfaat ekonomi dari Penggunaan Pengetahuan Tradisional dan Ekspresi Budaya Tradisional dilakukan

14 Penjelasan Pasal 38 ayat 1 memberikan definisi yang dimaksud dengan "ekspresi budaya tradisional” mencakup salah satu atau kombinasi bentuk ekspresi sebagai berikut: a. verbal tekstual, baik lisan maupun tulisan, yang berbentuk prosa maupun puisi, dalam berbagai tema dan kandungan isi pesan, yang dapat berupa karya sastra ataupun narasi informatif; b. musik, mencakup antara lain, vokal, instrumental, atau kombinasinya; c. gerak, mencakup antara lain, tarian; $d$. teater, mencakup antara lain, pertunjukan wayang dan sandiwara rakyat; e. seni rupa, baik dalam bentuk dua dimensi maupun tiga dimensi yang terbuat dari berbagai macam bahan seperti kulit, kayu, bambu, logam, batu, keramik, kertas, tekstil, dan lain-lain atau kombinasinya; dan f. upacara adat. 
untuk: a.mengembangkan Pengetahuan Tradisional dan Ekspresi Budaya Tradisional; atau b. membuka peluang bagi masyarakat dalam memperoleh manfaat ekonomi dari Pengetahuan Tradisional dan Ekspresi Budaya Tradisional".

Berpijak pada uraian tersebut di atas, walaupun dalam UUHC dan RUU PTEBT mengatur dengan jelas bahwa negara lah yang bertangggung jawab dalam mengelola ekspresi budaya tradisional. Namun demikian, objek ekspresi budaya tradisional dan subjek pihak yang memiliki kewenangan dalam pengelolaan ekspresi budaya tradisional dalam rangka memenuhi hak-hak masyarakat tradisional sebagai custodian lebih tegas diatur dalam RUU PTEBT sebagaimana diatur dalam Pasal 19 RUU PTEBT yaitu "Pemerintah dan Pemerintah Daerah bertanggung jawab mendorong Pemanfaatan Pengetahuan Tradisional dan Ekspresi Budaya Tradisional sebagai sumber ekonomi kreatif dengan tujuan utama untuk kesejahteraan anggota Masyarakat Pengembannya (custodian)". Dalam hal ini, benefit sharing sangat penting guna mewujudkan kesejahteraan masyarakat tradisional, baik dalam bentuk; a. pemberian kompensasi moneter, b. kompensasi non moneter. Benefit sharing dalam bentuk kompensasi moneter dapat berupa pembayaran tunai ataupun royalti berkelanjutan, sedangkan kompensasi non moneter adalah model yang telah dipraktekkan berabad-abad di Indonesia, dimana telah memperkaya ekspresi budaya tradisional Indonesia, yaitu produk atau karya baru yang merupakan turunan/ pengembangan ekspresi budaya tradisional Indonesia harus "dikembalikan" dan tersedia bagi masyarakat yang telah memelihara ekspresi budaya tradisional yang bersangkutan.

Berikutnya kelemahan pengaturan EBT dalam UUHC adalah terkait dengan Pasal 38 ayat (2) dimana negara wajib menginventarisasi, menjaga dan memelihara ekspresi budaya tradisional. Namun dalam tataran praksis, hingga saat ini belum ada database dokumentasi dan inventarisasi yang dibuat negara untuk mengkompilasi karyakarya yang dikategorikan sebagai ekspresi budaya tradisional Indonesia. Demikian juga dengan Pasal 38 ayat (4) yang menyatakan bahwa ketentuan lebih lanjut mengenai Hak Cipta yang dipegang oleh Negara atas ekspresi budaya tradisional diatur dengan Peraturan Pemerintah. Namun demikian, hingga saat ini belum ada peraturan pemerintah mengenai hak cipta yang dipegang oleh negara terkait ekspresi budaya tradisional. Tanpa adanya database dokumentasi dan inventarisasi atas ekspresi budaya tradisional dan peraturan pemerintah yang mengatur lebih lanjut hak cipta ekspresi budaya tradisional yang dipegang oleh negara maka akan menjadi sulit untuk mewujudkan perlindungan hukum terhadap ekspresi budaya tradisional Indonesia.

Terkait dengan hal tersebut, ekspresi budaya tradisional sebagai bagian kecil dari kebudayaan dalam wujudnya melahirkan tiga bentuk, yaitu: pertama, sebagai wujud yang 
muncul dari suatu kompleks ide-ide, gagasan, nilai, norma, peraturan dan sebagainya. Kedua, sebagai wujud dari suatu kompleksitas aktivitas serta tindakan berpola dari tingkah laku manusia dalam masyarakat. Ketiga, sebagai benda hasil karya manusia. Karya nyata yang dikenal dengan ekspresi budaya tradisional ini memiliki ciri-ciri khusus sebagai berikut: ${ }^{15}$

1. diajarkan dan dilaksanakan dari generasi ke generasi

2. merupakan pengetahuan yang meliputi pengetahuan tentang lingkungan dan hubungannya dengan segala sesuatu

3. bersifat holistik, sehingga tidak dapat dipisahkan dari masyarakat yang membangunnya

4. merupakan jalam hidup (way of life) yang digunakan secara bersama-sama oleh komunitas masyarakat, dan karenanya disana terdapat nilai-nilai masyarakat.

Berdasarkan ciri-ciri tersebut maka karakteristik yang dimiliki oleh ekspresi budaya tradisional tidak dimiliki oleh karya intelektual yang lain sebagaimana terdapat pada nomor 1, 3, dan 4. Secara keseluruhan yang disebut dengan ekspresi budaya tradisional adalah memenuhi syarat kumulatif keempat unsur tersebut yang menjadi unsur penting untuk menentukan karya intelektual sebagai ekspresi budaya tradisional.

Indonesia dalam UUHC menetapkan perlindungan hak cipta diberikan pada ciptaan yang bersifat pribadi dengan persyaratan yang memenuhi keaslian (originality), perwujudan (fixation) dan bersifat hak pribadi (individual right), berdasarkan kemampuan pikiran, imajinasi, kreativitas dan dalam bentuk yang khas. Dalam hal ini konsep perlindungan hak cipta yang dianut di Indonesia adalah adanya "ciptaan yang bersifat pribadi" yang dalam Negara Civil Law disebut dengan natural person. ${ }^{16}$ Ciptaan yang bersifat pribadi ini yang kemudian tidak dapat diterapkan dalam ekspresi budaya tradisional yang ada di Indonesia. Hal ini terjadi karena ekspresi budaya tradisional muncul, tumbuh dan berkembang dalam sebuah masyarakat tradisional dengan nilai-nilai kepemilikan yang komunal, sehingga tidak bisa diklaim sebagai milik individu. Hal ini terjadi karena ekspresi budaya tradisional sampai saat ini dikenal sebagai satu bentuk tradisi milik bersama tanpa ada yang mampu menguraikan siapa pencipta yang sebenarnya. Inilah yang menjadi alasan hukum ekspresi budaya tradisional mendapatkan perlindungan hukum tanpa batas waktu sebagaimana diatur dalam Pasal 60 ayat (1) UUHC, yaitu; "Hak Cipta atas ekspresi budaya tradisional yang dipegang oleh negara sebagaimana dimaksud dalam Pasal 38 ayat (1) berlaku tanpa batas waktu".

Terkait dengan hal tersebut, perlindungan terhadap ekspresi budaya tradisional sudah seharusnya berlangsung tanpa batas waktu (perpetual). Hal ini disebabkan ekspresi budaya tradisional mengandung nilai-nilai 
suci dan sakral yang hidup dalam suatu masyarakat yang telah diturunkan dari generasi ke generasi. Adakalanya ekspresi budaya tradional juga mengandung suatu rahasia yang hanya diketahui oleh masyarakat pemiliknya. ${ }^{17}$ Tanpa adanya perlindungan yang abadi maka ekspresi budaya tradisional akan menjadi public domain dan rentan terhadap eksploitasi dan penyalahgunaan oleh pihak asing. Klaim kepemilikan atas ekspresi budaya tradisional yang dilakukan pihak asing telah melukai masyarakat pemilik ekspresi budaya tradisional. Lebih jauh, bagi masyarakat ekspresi budaya tradisonal telah menjadi cara hidup mereka. Ekspresi budaya tradisional mengajarkan tradisi, kearifan, nilai-nilai, pengetahuan komunal yang dikemas dan diturunkan ke anak cucu melalui hikayat, legenda, kesenian, upacara yang berangsur-angsur membentuk norma sosial dan tata hidup. Hilangnya ekspresi budaya tradisonal berarti hilangnya juga norma sosial dan tradisi yang membawa implikasi sosial, seperti ketegangan pertikaian antar komunitas yang umum ditemui di negara-negara multietnik. $^{18}$ Dengan perlindungan yang bersifat abadi maka ekspresi budaya tradisonal akan terhindar dari penyalahgunaan dan eksploitasi tidak layak yang sangat melukai nilai sosial dan nilai budaya dari masyarakat tradisional.
Menguatkan uraian tersebut di atas, Mira Burry menyatakan kelemahan perlindungan EBT dalam hak cipta karena beberapa hal berikut ini; 19

\section{Originality (Orisinalitas)}

perlindungan hak cipta hanya pada karya asli, dan banyak lagi tradisi produksi seni dan sastra tidak asli dalam pengertian ini. Demikian pula, desain tradisional tidak dianggap asli untuk perlindungan desain industri.

\section{Ownership (Kepemilikan)}

perlindungan hak cipta memerlukan identifikasi pencipta atau pencipta individu yang dikenal untuk menentukan pemegang hak. Namun sulit, bahkan menjadi tidak mungkin untuk mengidentifikasi pencipta EBT dan karenanya pemegang hak dan penerima manfaat EBT dibuat dan dipegang secara komunal, atau karena pencipta tidak diketahui atau tidak dapat dipindahkan. Konsep kepemilikan dalam pengertian HKI juga asing bagi banyak masyarakat tradisional.

\section{Fixation (Fiksasi)}

Persyaratan fiksasi yang ada dalam banyak undang-undang hak cipta nasional mencegah ekspresi budaya tak benda dan lisan, seperti dongeng, tarian,

17 Hal ini berkesesuaian dengan Pasal 20 ayat (1) RUU PTEBT, yaitu "Setiap orang yang memanfaatkan Pengetahuan Tradisional dan Ekspresi Budaya Tradisional wajib menghormati aspek religius, spiritualitas, kepercayaan dan sifat rahasia dari Pengetahuan Tradisional dan Ekspresi Budaya Tradisional".

18 Afifah Kusumadara, Op.Cit., hlm. 20-41.

19 Mira Burri, Digital Technologies and Traditional Cultural Expressions: A Positive Look at a Difficultt Relationship, International Journal of Cultural Property, www.researchgate.net, October 2009, p. 8, accessed 26 Desember 2019. 
atau lagu, agar tidak dilindungi, kecuali diperbaiki dalam bentuk atau media tertentu. Bahkan ekspresi tetap tertentu, seperti lukisan wajah, lukisan tubuh, dan ukiran pasir, mungkin tidak memenuhi persyaratan.

4. The Limit of Protection (Batas Perlindungan)

Hak perlindungan terbatas atas hak cipta, hak terkait, dan desain industri diklaim tidak sesuai untuk EBT. Tidak dapat memenuhi kebutuhan untuk melindungi EBT selamanya atau setidaknya selama masyarakat ada. Jangka waktu perlindungan terbatas juga memerlukan kepastian sampai tanggal pembuatan karya atau publikasi pertama, yang sering tidak diketahui dalam kasus EBT.

5. Exceptions andLimitations (Pengecualian dan pembatasan)

Dalam hal ini pengecualian dan batasan lain yang umum ditemukan dalamundangundang hak cipta tidak cocok untuk EBT. Misalnya, pengecualian hak cipta khas yang memungkinkan patung atau karya pengerjaan artistik yang dipajang secara permanen di tempat umum untuk direproduksi dalam foto atau gambar tanpa izin dapat sangat mengganggu kepekaan adat dan melemahkan hak-hak adat.

6. Defensive Protection (Perlindungan
Defensif)
Masyarakat tradisional sangat prihatin terhadap perusahaan dan pihak asing yang meniru atau menyalin EBT mereka atau menggunakannya sebagai sumber inspirasi, dan kemudian memperoleh perlindungan HKI atas karya turunan mereka, desain, merek, atau produksi lainnya.

Kelemahan perlindungan ekspresi budaya tradisional dalam HKI juga karena adanya perbedaan konsep hak milik. Bagi masyarakat Indonesia, hak milik memiliki fungsi sosial yang boleh dinikmati oleh masyarakat lainnya, bagi sebagian besar masyarakat Indonesia, khususnya pemegang HKI, selama ini tidak dipandang sebagai pelanggaran serius bila HKI-nya dimanfaatkan atau dipergunakan oleh orang lain, meskipun tanpa melalui ijin si pemegang benda tersebut. ${ }^{20}$ Konsep ini berbeda dengan HKI yang berasal dari Barat di mana dalam konsep Barat, setiap pemanfaatan atas kepemilikan seseorang dapat dianggap sebagai pelanggaran HKI apabila tidak mendapat ijin dari pemiliknya secara sah.

Terkait dengan hal tersebut, disamping mengandung nilai sosial dan budaya, ekspresi budaya tradisional juga mengandung nilai ekonomi. Yaitu pada umumnya ekspresi budaya tradisional diciptakan oleh masyarakat tradisonal secara berkelompok, bahkan karyakarya ekspresi budaya tradisonal juga dapat dikembangkan oleh orang yang berbeda selama jangka waktu panjang sehingga

20 Adi Sulistiyono, Mekanisme Penyelesaian Sengketa HaKI (Hak atas Kekayaan Intelektual), Solo: Sebelas Maret University Press, 2004, hlm. 34 dalam Eva Dewi Kartika, Perlindungan Hukum atas Cerita Rakyat yang Ditulis oleh Pencipta Dalam Rangka Benefit Sharing, Jurnal Hukum \& Pembangunan Tahun ke-48 No.2, (April-Juni 2018): 384, diakses 17 Januari 2020. 
banyak masyarakat tradisional yang tidak mengenal konsep individu, harta berfungsi sosial dan bersifat milik umum. Dalam hal ini, para pencipta dalam masyarakat tradisional tidak berniat atau ingin mementingkan hak individu atau hak kepemilikan atas karyakarya mereka. ${ }^{21}$ Disisi lain ekspresi budaya tradisional memiliki potensi ekonomi yang menjanjikan terutama terkait dengan industri pariwisata dan industri ekonomi kreatif. Keberadaan hak eksklusif melekat erat kepada pemiliknya atau pemegangnya yang merupakan kekuasaan pribadi atas ciptaan yang bersangkutan. Dengan hak eksklusif, seorang pencipta/ pemegang hak cipta mempunyai hak untuk mengumumkan, memperbanyak ciptaannya serta memberi izin kepada pihak lain untuk melakukan perbuatan tersebut yang dikenal dengan hak ekonomi.

Hak ekonomi adalah hak untuk mendapatkan manfaat ekonomi atas ciptaan serta produk hak terkait. Ada 8 (delapan) jenis hak ekonomi yang melekat pada hak cipta, yaitu:22

1. Hak reproduksi (reproduction right) yakni hak untuk menggandakan atau memperbanyak ciptaan;

2. Hak adaptasi (adaptation right) yakni hak untuk mengadakan adaptasi terhadap hak ciptayangsudah ada;
3. Hak distribusi (distribution right) yakni hak untuk menyebarkan kepada masyarakat setiap hasil ciptaan dalam bentuk penjualan atau penyewaan;

4. Hak pertunjukkan (performance right) yakni hak untuk mengungkapkan karya seni dalam bentuk pertunjukkan atau penampilan oleh pemusik, dramawan, seniman, peragawati;

5. Hak penyiaran (broadcasting right) yakni hak untuk menyiarkan ciptaan melalui transmisi dan transmisi ulang;

6. Hak program kabel (cablecasting right) yakni hak untuk menyiarkan ciptaan melalui kabel;

7. Droit de Suit yakni hak tambahan pencipta yang bersifatkebendaan;

8. Hak pinjam masyarakat (public lending right) yakni hak pencipta atas pembayaran ciptaan yang tersimpan di perpustakaan umum yang dipinjam oleh masyarakat.

Dengan mewujudkan perlindungan terhadap ekspesi budaya tradisional maka diharapkan nilai ekonomi ekspresi budaya tradisional dapat mewujudkan kesejahteraan bagi masyarakat tradisional. Dan yang tak kalah pentingnya adalah menjaga budaya bangsa Indonesia dari ancaman pengakuan oleh negara lain atau pemanfaatan tanpa hak oleh warganegara asing. ${ }^{23}$

21 Laina Rafian dan Qoliqina Zolla Sabrina, Op.Cit., hlm. 499-500.

22 Abdul Atsar, "Perlindungan Hukum Terhadap Pengetahuan dan Ekspresi Budaya Tradisional Untuk Meningkatkan Kesejahteraan Masyarakat Ditinjau Dari Undang-Undang Nomor 5 Tahun 2017 tentang Pemajuan Kebudayaan dan Undang-Undang Nomor 28 Tahun 2014 tentang Hak Cipta”, Jurnal Law Reform Vol. 13, No. 2, (2017): 297, diakses 5 Maret 2018.

23 Di dalam Bab VI, Perlindungan Pasal 34 ayat (1) RUU PTEBT, "Pemerintah melakukan langkah-langkah untuk melindungi Pengetahuan Tradisional dan Ekspresi Budaya Tradisional dari Penggunaan pihak-pihak luar, baik orang asing maupun pelaku ekonomi”. Kemudian dalam Pasal 36 ayat (1) RUU PTEBT mengatur, "Untuk tujuan komersial setiap orang dilarang: a. melakukan penyalahgunaan Pengetahuan Tradisional dan Ekspresi Budaya Tradisional b. memberikan informasi yang salah; dan atau c. mengambil secara tidak sah”. 
Terkait dengan hal tersebut Pasal 37 RUU PTEBT menyatakan bahwa "Pemerintah dan atau Pemerintah Daerah wajib memastikan pelaksanaan pemenuhan hak masyarakat atas Pemanfaatan Pengetahuan Tradisional dan Ekspresi Budaya Tradisional oleh orang asing dan/ atau pelaku ekonomi”. Kemudian Pasal 38 RUU PTEBT mengatur lebih lanjut, yaitu;

1. Pemerintah dan/ atau Pemeintah Daerah berwenang mengatur akses terhadap Pengetahuan Tradisional dan Ekspresi Budaya Tradisional yang dilakukan oleh pelaku ekonomi dan/atau Insan Budaya.

2. Akses terhadap Pengetahuan Tradisional hanya dapat dilakukan setelah pelaku ekonomi mendapatkan PADIA.

3. Akses terhadap Ekspresi Budaya Tradisional dilakukan setelah pelaku ekonomi mendapatkan PADIA atau persetujuan/ tidak adanya penolakan dari Masyarakat Pengemban. ${ }^{24}$

4. Apabila akses dan Pemanfaatan sebagaimana dimaksud pada ayat (2) dilakukan tanpa PADIA, kesepakatan bersama dan pembagian manfaat yang adil dan seimbang, akses dan Pemanfaatan tersebut dapat dikategorikan:

a. Pemberian informasi yang salah dan menyesatkan tentang Pengetahuan Tradisional dan Ekspresi Budaya Tradisional untuk tujuan komersial (misrepresentation); b. Pengambilan secara tidak sah (misappropriation); atau

c. Penyalahgunaan (misuse)

Terkait dengan hal tersebut Pasal 40 RUU PTEBT mengatur “ Pemerintah dan/ atau Pemerintah Daerah wajib memfasilitasi masyarakat dalam Pemanfaatan Pengetahuan Tradisional dan Ekspresi Budaya Tradisional secara komersial dan/ atau non komersial agar masyarakat memperoleh manfaat ekonomi dari Pemanfaatan yang bersangkutan".

Dengan melakukan perbandingan pengaturan ekspresi budaya tradisional dalam UUHC dan RUU PTEBT maka semakin memperjelas bahwa perbedaan karakteristik antara hak cipta dengan ekspresi budaya tradisonal sangat menyulitkan untuk mewujudkan perlindungan ekspresi budaya tradisional dalam UUHC. ${ }^{25}$ Hal ini disebabkan karena ekspresi budaya tradisonal kurang sesuai dengan prinsip perlindungan yang terdapat dalam UUHC. Ketidaksesuaian tersebut antara lain karena prinsip dalam hak cipta merupakan kepemilikan perorangan (individual) sedangkan ekspresi budaya tradisional merupakan kepemilikan kolektif (communal). ${ }^{26}$ Selain itu, ekspresi budaya

24 Berdasarkan Pasal 1 angka 15 PADIA untuk Ekspresi Budaya Tradisional adalah persetujuan tertulis, lisan dan/ atau diam-diam terhadap Ekspresi Budaya Tradisional yang diberikan oleh masyarakat pengemban kepada Pengguna sebelum dilaksanakannnya pengembangan, pemanfaatan, dan/ atau promosi.

25 Beberapa negara mengatur ekspresi budaya tradisional sebagai bagian dari Undang-undang Hak Cipta, seperti Indonesia, Australia, Barbados, Iran, Nigeria, Kongo, dan Ghana. Di sisi lain, beberapa negara mengatur ekspresi budaya tradisional secara sui generis dalam undang-undang yang khusus mengatur ekspresi budaya tradisional seperti Kroasia, Filipina, Vietnam, Azerbaijan, dan Panama. Lihat Yusna Melianti, Julia Ivanna, Reh Bungana Beru Perangin-angin, PENGATURAN FOLKLOR SECARA SUI GENERIS DALAM UNDANGUNDANG TERSENDIRI, Masalah - Masalah Hukum, Jilid 45 No. 1, Januari 2016, diakses 17 Januari 2020.

26 Lebih lanjut lihat Jake Philips, "Australia's Heritage Protection Act : An Alternative to Copyright in the Struggle to Protect Communal Interests in Authored Works of Folklore", Pacific Rim and Policy Journal, 18 Pac. Rim L. \& Pol'y J. 547, August 2009, p. 549, accessed 17 Januari 2020. 
tradisional sering tidak diketahui siapa penciptanya dan tidak orisinil (asli) karena diwariskan secara turun temurun. ${ }^{27}$ Adapun persyaratan dalam perlindungan hak cipta adalah harus jelas siapa yang menjadi pencipta $^{28}$ dan ciptaan harus bersifat orisinil. ${ }^{29}$ Dengan demikian, UUHC kurang sesuai untuk melindungi ekspresi budaya tradisional, ${ }^{30}$ sehingga sudah seharusnya ekspresi budaya tradisonal dilindungi secara tersendiri dalam undang-undang yang khusus mengatur ekspresi budaya tradisional. Atas dasar inilah, pengaturan ekspresi budaya tradisional secara sui generis dengan segera mengesahkan RUU PTEBT lebih tepat dalam kerangka mewujudkan perlindungan hukum ekspresi budaya tradisional Indonesia. Unsur-unsur sistem sui generis untuk EBT diantaranya meliputi:

1. Pertimbangan/ kebijakan yang mendasari diperlukannya sui generis dimaksud;

2. Subyek yang diatur;

3. Kriteria yang harus dipenuhi oleh subyek dimaksud;

4. Pemilik;

5. Hak dan kewajiban apa yang dimiliki oleh pemilik;
6. Ruang lingkup objek yang dilindungi

7. Bagaimana prosedur untuk memperoleh hak;

8. Lembaga yang berwenang dalam prosedur administrasi

9. Bagaimana cara mengadministrasikan dan menegakkan hak dimaksud;

10. Penyelesaian sengketa;

11. Mekanisme pembagian keuntungan dalam perjanjian kontrak yang melibatkan investor asing;

12. Pengaturan dokumentasi mengenai EBT yang tersusun dalam database;

13. Menyusun standar dokumentasi hak kekayaan intelektual yang sesuai untuk EBT;

14. Pertukaran informasi EBT secara elektronik/online.

Substansi yang terpenting dari sistem sui generis yang dimaksud adalah adanya pengakuan yang tegas bahwa masyarakat tradisional adalah "pemilik" dari EBT yang bersangkutan. Hukum adat atau hukum kebiasaan (customary law) dapat menjadi salah satu alternatif sumber atau bahan untuk merumuskan hak-hak masyarakat tradisional

27 Lebih lanjut lihat Stephanie Spangler, "When Indigenous Communities Go Digital : Protecting Traditional Cultural Expressions Through Integration of IP and Customary Law", 27 Cardozo Arts \& Ent.L.J.709., Cardozo Arts and Entertainment Law Journal, 2010, p. 711, accessed 17 Januari 2020.

28 Lebih lanjut lihat Susanna Frederick Fischer, "Dick Whittington And Creativity: From Trade To Folklore, From Folklore To Trade", Symposium "The Power of Stories: Intersections of Law, Literature, and Culture The Dick Whittington Story: Its Influences \& Its Impacts, 12 Tex. Wesleyan L. Rev. 5, Texas Wesleyan Law Review, Fall 2005, p. 20, accessed 17 Januari 2020.

29 Lebih lanjut lihat Molly Torsen, "Intellectual Property And Traditional Cultural Expressions: A Synopsis Of Current Issues", 3 Intercultural Hum. Rts. L. Rev. 199, Intercultural Human Rights Law Review, 2008, p. 203, accessed 17 Januari 2020.

30 Lebih lanjut lihat Silke von Lewinski, “The Protection Of Folklore”, 11 Cardozo J. Int'l \& Comp. L. 747, Cardozo Journal of International and Comparative Law, Summer 2003, p. 757, accessed 17 Januari 2020. 
tersebut di dalam Undang-undang suigeneris. ${ }^{31}$ Sistem sui generis yang dimaksud tidak mengabaikan unsur-unsur yang berlandaskan pada norma agama sesuai dengan sifat hukum adat yang religio magis, bersifat sederhana, dan berlandaskan kepada sistem kemasyarakatan yang sangat menghargai kebersamaan. ${ }^{32}$ Hal ini dipertegas oleh Pamela Adanda bahwa ; “ sui generis protection entails an acquisition of an alternative right that is separate from the rights that are recognized under the formal IP system"33, sehingga harapan untuk pemenuhan hak-hak masyarakat tradisional atas ekspresi budaya tradisional dapat terpenuhi guna terwujudnya keadilan dan kesejahteraan.

\section{B. Perlindungan Ekspresi Budaya Tradisional dalam Konvensi Internasional}

Dalam rangka perlindungan ekspresi budaya tradisional Indonesia dalam sistem sui generis, maka konvensi internasional dapat dijadikan sebagai rujukan dasar hukum. Dalam hal ini Pasal 2 paragraf viii Agreement Establishing the WIPO, menyatakan “intellectual property" termasuk di dalamnya yaitu: “. . . and all other rights resulting from intellectual activity in the industrial, scientific, literary or artistic fields". Artinya, kekayaan intelektual meliputi hak-hak lain dari aktivitas intelektual dalam bidang industri, ilmu pengetahuan, seni dan sastra. Selanjutnya dalam Pasal 8 paragraf $\mathrm{j}$ Convention on Biological Diversity 1992 (CBD Convention) mewajibkan negara anggotanya untuk menghormati, melestarikan dan memelihara pengetahuan, inovasi dan praktik masyarakat adat dan lokal yang mewujudkan gaya hidup tradisional yang relevan untuk konservasi dan pemanfaatan keanekaragaman hayati secara berkelanjutan dan mempromosikan aplikasi mereka yang lebih luas dengan persetujuan dan keterlibatan para pemegang pengetahuan, inovasi dan praktik seperti itu dan mendorong pembagian yang adil dari pembagian manfaat. Dari pemanfaatan pengetahuan, inovasi, dan praktik tersebut maka diharapkan dapat mewujudkan kesejahteraan masyarakat tradisional.

31 Sebagaimana dinyatakan oleh Meghana Rao Rane “...his Comment argues that the mainstream solutions proposed for the protection of TCEs, namely the use of existing IPRs and sui generis solutions, are sub-optimal, and the indigenous customary laws of the communities seeking protection are more effective and should be implemented instead". Lihat Meghana Rao Rane, Aiming Straight: The Use of Indigenous Customary Lawto Protect Traditional Cultural Expressions, PACIFIC RIM LAW \& POLICY JOURNAL VOL. 15 NO. 3, p. 830, accessed 17 Januari 2020.

32 Muthia Septarina, Perlindungan Hukum Pengetahuan Tradisional Dalam Konsep Hukum Kekayaan Intelektual, Al' Adl Volume VIII Nomor 2, Mei-Agustus 2016, hlm. 58.

33 Pamela Adanda, "Striking a Balance between Intellectual Property Protection of Traditional Knowledge, Cultural Preservation and Access to Knowledge", Journal of Intellectual Property Rights, Vol. 17, November 2012, p. 551, accessed 2 Mei 2020. Namun demikian, dalam perkembangannya terdapat kontroversi dalam perlindungan sistem sui generis karena alasan; pertama, hal itu mungkin akhirnya menghambat akses ke barang pengetahuan yang terjangkau bahkan untuk masyarakat adat dan lokal. Kedua, ada keragaman pandangan tentang sifat rezim yang dibayangkan. Lihat Oseitutu J.J., A sui generis regime for traditional knowledge; the cultural divide in intellectual property law, The Marquette Intellectual Property Law Review, 15 (1), 2011, p. 101-112, accessed 2 Mei 2020. 
Terkait hal tersebut, Komite antar negara yaitu Intergovernmental Committee on intellectual Property and Genetic Resources, Traditional Knowledge and Folklore (IGC GRTKF) yang berfungsi sebagai forum di mana negara anggota WIPO membahas isu-isu kekayaan intelektual yang timbul dalam konteks sumber daya genetik, perlindungan pengetahuan tradisional dan ekspresi budaya tadisional. Pada Tahun 2010, anggota WIPO memutuskan bahwa IGC GRTKF harus memulai negosiasi formal dengan tujuan mencapai kesepakatan mengenai satu atau lebih instrumen hukum internasional yang akan menjamin perlindungan yang efektif dalam sumber daya genetik, pengetahuan tradisional dan ekspresi budaya tradisional.

Sampai saat ini IGC GRTKF mencapai sesi ke-38 yang dilangsungkan pada tanggal 10-14 Desember 2018 di Jenewa. Berdasarkan WIPO/GRTKF/IC/38/INF/7 28 September, 2018 pertemuan ini pun masih menghasilkan draft treaties yang memuat hingga 12 pasal. Beberapa draft yang dibahas ada beberapa tambahan antara lain:

1. Pasal 2 mengenai manfaat dari perlindungan ekspresi budaya tradisonal, yaitu masyarakat tradisional yang membuat, memelihara, menggunakan dan/ atau mengembangkan materi permasalahan kriteria kelayakan ekspresi budaya tradisional yang ditetapkan.

2. Pasal 3 mengenai kriteria dan lingkup perlindungan yang menyatakan bahwa pengetahuan tradisional dan ekspresi budaya tradisional yang dilindungi adalah suci, rahasia dan dimiliki oleh masyarakat tradisional wajib dipelihara oleh negara atau pihak lain. Apabila itu sesuatu yang "sakral" maka tidak boleh ada penyimpangan (misleading use). Sedangkan bila itu sesuatu yang "tidak disakralkan" maka harus ada benefit sharing bagi masyarakat tradisional.

3. Pasal 4 mengenai sanksi bahwa negara atau negara anggota harus memastikan hukum dinegara masing-masing memadai mengenai pengetahuan tradisional dan ekspresi budaya tradisional.

Indonesia sebagai anggota WTO dan WIPO maka dalam kerangka mendukung perlindungan ekspresi budaya tradisional dipertegas kembali dengan meratifikasi Convention for the Safeguarding of the Intangible Cultural Heritage dalam Peraturan Presiden Republik Indonesia Nomor 78 tahun 2007 tentang Pengesahan Convention for the Safeguarding of the Intangible Cultural Heritage (Konvensi Untuk Perlindungan Warisan Budaya Tak Benda) di tahun 2003. Kemudian Tahun 2005, Indonesia menyepakati Convention on the Protection and Promotion of the Diversity of Cultural Expression dalam forum United Nations Education, Scientific, and Cultural (Organization (UNESCO) yang diratifikasi dengan Peraturan Presiden Republik Indonesia Nomor 78 tahun 2011 tentang Pengesahan Convention on the Protection and Promotion of the Diversity of Cultural Expression 
(Konvensi tentang Proteksi dan Promosi Keanekaragaman Ekspresi Budaya). Dalam konvensi-konvensi tersebut telah diuraikan mengenai pentingnya perlindungan terhadap pengetahuan tradisional dan ekspresi budaya tradisional. Juga memberikan jalan bagi negara-negara berkembang agar dapat melindungi pengetahuan tradisional dan ekspresi budaya tradisionalnya. Oleh karena itu, Indonesia sebagai negara berkembang dapat menjadikan konvensi tersebut sebagai pedoman dalam membentuk undang-undang sui generis. Dalam dimensi HKI, kedua Konvensi UNESCO tersebut menegaskan pentingnya perlindungan hak moral komunal dan bahkan hak moral suatu bangsa terhadap warisan budaya yang berasal dari anggotaanggota UNESCO.

Namun demikian, hingga saat ini belum ada keseragaman pengertian dan ruang lingkup yang termasuk ke dalam ekspresi budaya tradisional baik dalam tingkat nasional maupun intemasional. Sehingga kadang menimbulkan kebingungan dan kerancuan tentang apa saja yang termasuk ke dalam ekspesi budaya tradisonal. Tanpa adanya pengertian dan ruang lingkup yang jelas atas ekspresi budaya tradisional, maka perlindungan terhadap ekspresi budaya tradisonal tidak akan maksimal. Hal ini disebabkan, apa yang merupakan objek ekspresi budaya tradisional bagi suatu negara belum tentu merupakan objek ekspresi budaya tradisional bagi negara lainnya, demikian juga pengaturan dalam hukum nasional maupun internasional.

Adapun pengertian dan ruang lingkup ekspresi budaya tradisional menurut hukum adalah sebagai berikut:

a. verbal tekstual, baik lisan maupun tulisan, yang berbentuk prosa maupun puisi, dalam berbagai tema dan kandungan isi pesan, yang dapat berupa karya sastra ataupun narasi informatif;

b. musik, mencakup antara lain: vokal, instrumental atau kombinasinya;

c. gerak, mencakup antara lain: tarian, beladiri, dan permainan;

d. teater, mencakup antara lain: pertunjukan wayang dan sandiwara rakyat;

e. seni rupa, baik dalam bentuk dua dimensi maupun tiga dimensi yang tcrbuat dari berbagai macam bahan seperti kulit, kayu, bambu, logam, batu, keramik·, kertas, tekstil, dan lain-lain atau kombinasinya;

f. hasil seni antara lain bcrupa perhiasan, kerajinan tangan, instrumen musik, pakaian dan tenun tradisional.

g. bentuk-bentuk arsitektur ${ }^{34}$

h. upacara dan ritual adat yang juga mencakup pembuatan alat dan bahan serta penyajiannya.

34 dalam UUHC bentuk arsitektur tidak dimasukan ke dalam ruang lingkup EBT yang dilindungi. Hal ini berbeda dengan ruang lingkup EBT dalam Model Provisions dan WIPO Revised Objectives and Principles for the Protection of Traditional Cultural Expressions and Expressions of Folklore yang memasukan architectural forms (bentuk-bentuk arsitektur) ke dalam ruang lingkup folklor. Namun demikian dalam Pasal 4 RUU PTEBT ruang lingkup EBT lebih luas, yaitu: "Ruang lingkup Ekspresi Budaya Tradisional meliputi; mencakup ekspresi fonetik atau verbal, ekspresi suara atau musik, ekspresi gerak atau tindakan, dan ekspresi material (kebendaan) maupun karya intelektual lainnya". 
Diharapkan dengan adanya keseragaman pengertian dan ruang lingkup ekspresi budaya tradisional baik menurut Hukum Nasional maupun Hukum Internasional maka akan lebih mudah dalam mewujudkan perlindungan hukum ekspresi budaya tradisional. Namun demikian, hingga saat ini masih belum ada keseragaman definisi dan ruang lingkup perlindungan terhadap ekspresi budaya tradisional sebagaimana uraian perbandingan Konvensi Internasional berikut;

The Draft Treaties WIPO
Intergovernmental Committee on Intellectual Property and Genetic Resources, Traditional Knowledge and Folklore (IGC GRTKF): Article 1: Definitions

(a) 'Traditional cultural expressions' or 'expressions offolklore' are any forms, wheter 'tangible' and 'intangible', in which traditional culture and knowledge are expressed, appear or are manifested, and comprise the following forms of expressions or combinations thereof;

(I) Verbal expressions, such as: stories, epics, legends, poetry, riddles and other narratives; words, signs, names, and symbols;

(II) Musical expressions, such as songs and instrumental music;

(III)Expressions by action, such as dances, plays, ceremonies, rituals and other performances, whether or not reduced to material form; and,

(IV) Tangible expressions, such as productions of art, in particular, drawings, designs, paintings (including body painting), carvings, sculptures, pottery, terracota, mosaic, woodwork, metalware, jewelry, baskets, needlework, textiles, glassware, carpets, costumes; handicrafts, musical, intruments; and architectural forms; Which are:

(c) The product of crative intellectual activity, including individual and communal creativity;

(d) Characteristic of a community's cultural and social identity and cultural heritage; and

(e) Maintained, used or develop by such communit, or by individuals havingthe right or responsibility to do so in accordance with the customary law and practices of that community.

The spesific choice of terms to denote the protected subject matter should be determined at the national and regional levels.

Berdasar Pasal 1 the Draft Treaties WIPO IGC GRTKF maka dapat diartikan disini bahwa ekspresi budaya tradisional adalah bentuk apa pun, baik 'berwujud' maupun 'tidak berwujud', di mana budaya dan pengetahuan tradisional diekspresikan, muncul atau dimanifestasikan, dan terdiri dari bentuk-bentuk ekspresi atau kombinasi berikut;

(i) Ekspresi verbal, seperti: cerita, epos, legenda, puisi, teka-teki, dan narasi lainnya; kata, tanda, nama, dan simbol; (ii) Ekspresi musik, seperti lagu dan musik instrumental; (iii) Ekspresi dengan tindakan, seperti tarian, sandiwara, upacara, ritual dan pertunjukan 
lainnya, baik direduksi menjadi materi atau tidak; dan, (iv) Ekspresi berwujud, seperti produksi seni, khususnya, gambar, desain, lukisan (termasuk lukisan tubuh), ukiran, patung, tembikar, terakota, mosaik, kerajinan kayu, barang logam, perhiasan, keranjang, menjahit, tekstil, barang pecah belah, karpet, kostum; kerajinan tangan, musik, instrumen; dan bentuk arsitektur; Yang mana: (a) Produk dari aktivitas intelektual kreatif, termasuk kreativitas individu dan komunal; (b) Karakteristik identitas budaya dan sosial masyarakat dan warisan budaya; dan (c) dipertahankan, digunakan atau dikembangkan oleh komunitas tersebut, atau oleh individu yang memiliki hak atau tanggung jawab untuk melakukannya sesuai dengan hukum adat dan praktik masyarakat itu.

Definisi ekspresi budaya tradisional dalam IGC GRTKF ini memberikan ruang lingkup perlindungan yang lebih luas dibandingkan dengan hukum nasional Indonesia, karena bisa meliputi benda yang 'tangible' dan 'intangible', sedangkan penjelasan Pasal 38 ayat (1) UUHC memberikan definisi ekspresi budaya tradisional dalam ruang lingkup benda yang 'intangible".

b. Convention on The Protection and Promotion of The Diversity of Cultural Expression Unesco 2005 (Konvensi Tentang Proteksi dan Promosi Keanekaragaman Ekspresi Budaya Unesco 2005)

The objectives of this Convention are: a. to protect and promote the diversity of cultural expressions;

b. to create the conditions for cultures to flourish and to freely interact in a mutually beneficial manner;

c. to encourage dialogue among cultures with a view to ensuring wider and balanced cultural exchanges in the world in favour of intercultural respect and a culture of peace;

d. to foster interculturality in order to develop cultural interaction in the spirit of building bridges among peoples;

e. to promote respect for the diversity of cultural expressions and raise awareness of its value at the local, national and international levels;

f. to reaffirm the importance of the link between culture and development for all countries, particularly for developing countries, and to support actions undertaken nationally and internationally to secure recognition of the true value of this link;

g. to give recognition to the distinctive nature of cultural activities, goods and services as vehicles of identity, values and meaning;

h. to reaffirm the sovereign rights of States to maintain, adopt and implement policies and measures that they deem appropriate for the protection and promotion of the diversity of cultural expressions on their territory; to strengthen international cooperation and solidarity in a spirit of partnership with a view, in particular, to enhancing the capacities of developing countries in order to protect and promote the diversity of cultural expressions. 
Article 3 Scope of application; "This Convention shall apply to the policies and measures adopted by the Parties related to the protection and promotion of the diversity of cultural expressions".

Berdasarkan Konvensi Unesco tersebut maka ruang lingkup konvensi meliputi kebijakan dan tindakan yang diadopsi oleh para pihak terkait dengan perlindungan dan promosi keanekaragaman ekspresi budaya. Dan yang dimaksud dengan perlindungan (protection) adalah langkah-langkah yang ditujukan untuk pelestarian, pengamanan, dan peningkatan keanekaragaman ekspresi budaya. Tujuan dari konvensi ini lebih luas, yaitu meliputi pelestarian, promosi, dan perlindungan terhadap ekspresi budaya, baik dalam bentuk ekspresi buday tradisional yang berwujud (tangible) maupun tidak berwujud (intangible).

c. Convention for The Safeguarding of The Intangible Cultural Heritage Unesco 2003

\section{Article 2: Definitions}

For the purposes of this Convention:

1. The "intangible cultural heritage" means the practices, representations, expressions, knowledge, skills-as well as the instruments, objects, artefacts and cultural spaces associated therewith -that communities, groups and, in some cases, individuals rerognize as part of their cultural heritage. This intangible cultural heritage, transmitted from generation to generation, is constantly recreated by communities and groups in response to their environment, their interaction with nature and their history; and provides them with a sense of identity and continuity, thus promoting respect for cultural diversity and human creativity. For the purposes of this Convention, consideration will be given solely to such intangible cultural heritage as is compatible with existing international human rights instruments, as well as with the requirements of mutual respect among communities, groups and individuals, and of sustainable development.

2. The "intangible cultural heritage", as defined in paragraph 1 above, is manifested inter alia in the following domains: (a)oral traditions and expressions, including language as a vehicle of the intangible cultural heritage; (b)performing arts; (c) social practices, rituals and festive events; (d)knowledge and practices concerning nature and the universe; (e)traditional craftsmanship.

3. "Safeguarding" means measures aimed at ensuring the viability of the intangible cultural heritage, including the identification, documentation, research, preservation, protection, promotion, enhancement, transmission, particularly through formal and non formal education, as well as the revitalization of the various aspects of such heritage.

Dapat diartikan disini bahwa berdasarkan Pasal 2 ayat (1) Convention for The Safeguarding of The Intangible Cultural Heritage 2003 yang dimaksud Warisan budaya takbenda adalah: "berbagai praktek, representasi, ekspresi, pengetahuan, keterampilan: serta instrumen-instrumen, obyek, artefak dan lingkungan budaya yang 
terkaitmeliputiberbagaikomunitas, kelompok, dan dalam beberapa hal tertentu, perseorangan yang diakui sebagai bagian warisan budaya mereka. Warisan budaya takbenda ini, diwariskan dari generasi ke generasi, secara terus-menerus diciptakan kembali oleh berbagai komunitas dan kelompok". Sebagai tanggapan mereka terhadap lingkungannya, interaksi mereka dengan alam, serta sejarahnya, dan memberikan mereka makna jati diri dan keberlanjutan, untuk memajukan penghormatan keanekaragaman budaya dan kreatifitas manusia. Untuk maksud-maksud Konvensi ini, pertimbangan akan diberikan hanya kepada warisan budaya takbenda yang selaras dengan instrumen-instrumen internasional yang ada mengenai hak-hak asasi manusia, serta segala persyaratan saling menghormati antar berbagai komunitas, kelompok, dan perseorangan, dan pembangunan yang berkelanjutan.

"Warisan budaya takbenda", sebagaimana dalam ayat (1) di atas, diwujudkan antara lain di bidang-bidang sebagai berikut:

a. tradisi dan ekspresi lisan, termasuk bahasa sebagai wahana warisan budaya takbenda;

b. seni pertunjukan;

c. adat istiadat masyarakat, ritus, dan perayaan-perayaan;

d. pengetahuan dan kebiasaan perilaku mengenai alam dan semesta;

e. kemahiran kerajinan tradisional. Selanjutnya yang dimaksud 'Perlindungan' dalam Konvensi tersebut adalah tindakan-tindakan yang bertujuan memastikan kelestarian warisan budaya takbenda, termasuk identifikasi, dokumentasi, penelitian, preservasi, perlindungan, pemajuan, peningkatan, penyebaran, khususnya melalui pendidikan, baik formal maupun nonformal, serta revitalisasi berbagai aspek warisan budaya tersebut.

Berdasarkan uraian tersebut maka definisi dan ruang lingkup dalam Convention for The Safeguarding of The Intangible Cultural Heritage 2003 berkesesuaian dengan Hukum Nasional Indonesia, yaitu UUHC yang memberikan definisi ekpresi budaya tradisional dalam ruang lingkup benda 'intangible'. Namun dalam hal ini RUU PTEBT lebih luas dalam memberikan perlindungan terhadap ekspresi budaya tradisional, yaitu meliputi ekspresi budaya tradisional yang berwujud (tangible) dan ekspresi budaya tradisional yang tidak berwujud (intangible) sedangkan Convention for The Safeguarding of The Intangible Cultural Heritage 2003 hanya melindungi warisan budaya dalam bentuk tidak berwujud.

d. Guidelines for developing national legislation for the protection of traditional knowledge and expressions of culture based on the Pacific Model Law 2002

Berdasar Pacific Model Law 2002 negaranegara dapat memilih untuk mengembangkan sistem nasional mereka sendiri atau memilih untuk menerapkan pendekatan regional (seperti Hukum Model Pasifik) atau pendekatan internasional. Masing-masing 
memiliki kelebihan dan kekurangannya sendiri, yaitu;

a. Pendekatan nasional: Manfaat mengembangkan sistem nasional 'dari awal' adalah memungkinkan suatu negara untuk mengembangkan langkah-langkah yang mencerminkan dan merespons keadaan khususnya. Namun, kerugiannya adalah bahwa dengan tidak adanya perjanjian bilateral atau multilateral yang memberikan perlindungan di yurisdiksi asing, perlindungan terbatas pada negara tertentu. Ini dapat mengarah pada situasi di mana sistem perlindungan ekspresi budaya tradisional di suatu negara berbeda dengan negara lain.

b. Pendekatan regional: Kerangka kerja regional dapat memberikan perlindungan yang lebih efektif daripada sistem nasional. Pendekatan kerangka kerja, seperti Kerangka Regional Pasifik untuk Perlindungan Pengetahuan Tradisional dan Ekspresi Budaya (yang menjadi bagian dari UU Model Pasifik), dapat mencapai harmonisasi di seluruh sistem nasional melalui penggunaan standar substantif minimum sambil memberikan fleksibilitas bagi negara-negara untuk memodifikasi dan mengadaptasi hal-hal detail agar sesuai dengan keadaan khusus mereka. Dalam pengertian ini, 'pendekatan regional' berarti kerangka kerja regional yang memandu hukum nasional dan memastikan tingkat kesamaan tertentu di antara mereka.
Namun, undang-undang nasional tetap bersifat nasional, dan penerapannya terbatas pada wilayah masing-masing. 'Sistem regional' juga dapat merujuk pada pendekatan yang lebih terintegrasi yang dapat memungkinkan, misalnya, saling pengakuan hak antara wilayah yang bergabung, penegakan timbal balik hak-hak di wilayah wilayah, dan mekanisme regional untuk penyelesaian sengketa. Ini sangat berguna di mana ekspresi budaya tradisional tertentu tidak terbatas pada satu negara, seperti halnya di Pasifik dan daerah lain.

c. Pendekatan internasional: Seringkali disarankan bahwa perlindungan komprehensif hanya dapat dicapai melalui sistem internasional. Sistem seperti itu kemungkinan terdiri dari norma-norma dan prinsip-prinsip, seperti yang dikembangkan dalam WIPO IGC GRTKF, dengan masalah-masalah detail diserahkan kepada tingkat nasional dan regional. Ini penting mengingat keanekaragaman budaya dunia serta keanekaragaman yurisprudensi. Ini juga realistis, mengingat beragam kepentingan dan keprihatinan negara-negara dengan posisi berdasarkan pada asumsi dan sudut pandang ideologis yang sangat berbeda mengenai pengetahuan tradisional dan kelompok-kelompok pemegang pengetahuan tradisional. Meskipun demikian, setiap rezim internasional yang menyediakan perlindungan 
hukum internasional yang efektif akan memerlukan tingkat harmonisasi, dan ini dapat dicapai melalui norma dan prinsip yang diadopsi di tingkat internasional. Suatu sistem internasional memiliki fitur utama dan paling menarik yaitu fasilitas untuk menegakkan hak-hak mengenai ekspresi budaya tradisional dari satu negara yang meratifikasi di negara yang meratifikasi lainnya (seperti perlindungan internasional untuk hak cipta yang diberikan oleh Berne Convention 1971). Diskusi terus berlanjut di WIPO IGC GRTKF tentang pengembangan dan adopsi sistem semacam itu. Sebagaimana dicatat, di tingkat internasional ada beragam kepentingan yang dipertaruhkan dan berbagai perspektif tentang masalah tersebut.

e. Berne Convention For The Protection of Literary And Artistic Works (Berne Convention as amended on September 28, 1979)

Dalam Berne Convention 1886 objek perlindungan hak cipta hanya karya-karya sastra dan seni yang meliputi segala hasil di bidang sastra, ilmiah dan kesenian dalam cara dan bentuk pengutaraan apapun. Ekspresi budaya tradisional belum dimasukkan dalam konvensi ini. Kemudian pada 14 Juli 1967 di Stockholm, dalam revisi atau penyempurnaan Berne Convention diperkenalkan suatu perlindungan terhadap Ciptaan yang tidak diketahui penciptanya, yaitu; "in the case of unpublised works where the identity of the author is unknown, but where there is every ground to presume that he is a national of a country of the Union, it shall be a matter for legislation in that country to design the component which shall represent the author and shall be entitled to protect and enforce his rights in the countries of the Union". ${ }^{35}$ Kemudian dalam revisi berikutnya pada tanggal 24 Juli 1971 di Paris ditambahkan bahwa "countries of the Union which makes such designation under the term of the provision shall notify the Director General (of WIPO) by means of a written declaration giving full information concerning the authority thus designated. The Director General shall at once communicate this declaration to all other countries of the Union". ${ }^{36}$

Konvensi ini dapat diterapkan untuk memberikan perlindungan hukum ekspresi budaya tradisional Indonesia yang tidak diketahui penciptanya.

f. The Tunis Model Law on Copyright for Developing Countries of 1976

Pada Tahun 1976, diperkenalkan the Tunis Model Law on Copyright for Developing Countries dalam hal perlindungan ekspresi budaya tradisional. Tunis Model Law ini diadopsi dari hasil sidang Committe of Govermental oleh Pemerintah Tunisia dengan WIPO dan Unesco yang dilaksanakan pada tanggal 23 Februari sampai dengan 2 Maret 
1976. Dalam Model tersebut diperkenalkan gagasan bahwa perlindungan ekspresi budaya tradisional tidak harus pada jenis ekspresi budaya tradisional yang berwujud (fixation), gagasan akan adanya hak-hak moral tertentu untuk melindungi dari pengrusakan dan pelecehan karya-karya tradisional dan juga gagasan bahwa perlindugnan ekspresi budaya tradisional tidak mengenal batas waktu.

Lebih lanjut lagi Tunis Model Law juga mengatur pelarangan penggunaan tanpa izin, penggunaan ekspresi budaya tradisional secara serampangan, dan pengaturan perlindungan internasional secara timbal balik antara negara-negara anggota pengguna ekspresi budaya tradisional. Juga ditetapkan perlu dibentuknya Badan Berwenang di setiap negara yang mewakili kepentingan komunitaskomunitas tradisional dalam melindungi ekspresi tradisional yang dimilikinya. ${ }^{37}$

Terkait dengan konvensi internasional perlindungan ekspresi budaya tradisional maka dalam model perlindungan yang dibuat oleh Group Kerja UNESCO dan WIPO tersebut, memiliki kriteria dengan memperhatikan: ${ }^{38}$

1. Pentingnya perlindungan hukum untuk kekspresi budaya tradisional yang memadai;

2. Perlindungan hukum terhdap ekspresi budaya tradisional harus diterapkan dalam undang-undang nasional;

3. Bentuk perlindungan ini menghargai perlindungan ekspresi budaya tradisional dengan adanya perlindungan hak cipta (copyright) dan hak terkait lainnya (neighboring rights);

4. Model perlindungan harus dibuat jelas dan rinci untuk penerapan bagi negara yang belum memiliki hukum nasional yang terkait dengan perlindungan ekspresi budaya tradisional dan negara yang telah memiliki hukum nasional terkait ekspresi budaya tradisional sehingga dapat dikembangkan lebih lanjut;

5. Bentuk perlindungan ekspresi budaya tradisional dalam hukum nasional harus terbuka bagi perlindungan ekspresi budaya tradisional secara sub regional, regional dan internasional.

Dengan demikian, konvensi-konvensi internasional tersebut dapat memperkuat perlindungan terhadap ekspresi budaya tradisional Indonesia dalam UUHC maupun sebagai rujukan pengaturan ekspresi budaya tradisional dalam sistem sui generis.

\section{Simpulan}

1. Pengaturan perlindungan hukum ekspresi budaya tradisional di Indonesia terdapat dalam Pasal 38 Undang-undang Nomor 28 Tahun 2014 tentang Hak Cipta. Namun demikian UUHC tidak mengatur secara jelas terhadap objek ekspresi budaya tradisional dan subjek selaku pihak yang berwenang mewakili negara dalam pengelolaan ekspresi budaya tradisional.

37 Tim Lidsey dkk, Hak Kekayaan Intelektual Suatu Pengantar, (Bandung: Alumni, 2002), hlm. 277-278.

38 World Intellectual Property Organization, Consolidated Analysis of the Legal Protectiona of Traditional Cultural Expression/ Expression of Folklore, Background Paper I, 2003, p. 23. 
Disamping itu belum adanya database dokumentasi dan inventarisasi ekspresi budaya tradisonal oleh pemerintah serta belum adanya peraturan pemerintah yang mengatur lebih lanjut terkait ciptaan ekspresi budaya tradisional yang dipegang oleh negara menjadi kelemahan dalam mewujudkan perlindungan ekspresi budaya tradisional dalam UUHC. Hal ini berbeda dengan RUU PTEBT yang lebih lengkap dan jelas dalam mengatur objek ekspresi budaya tradisonal dan subjek selaku pihak yang berwenang mewakili negara dalam pengelolaan ekspresi budaya tradisional sehingga pemenuhan hak-hak masyarakat tradisional guna mewujudkan kesejahteraan dan keadilan lebih terjamin. Disamping itu perbedaan karakteristik kepemilikan antara aturan hak cipta yang bersifat "privat right", dengan ekspresi budaya tradisional yang bersifat "communal right" menjadi kelemahan untuk memenuhi persyaratan perlindungan ekspresi budaya tradisional dalam UUHC yang meliputi keaslian (originality) dan perwujudan (fixation). Oleh karena itu sangat penting untuk melakukan pengesahan RUU PTEBT sebagai bentuk perlindungan ekspresi budaya tradisional Indonesia dalam sistem sui generis.

2. Berdasarkan konvensi internasional, perlindungan atas ekspresi budaya tradisional melalui pembentukan arsip dan dokumentasi nasional di tiap-tiap negara, sehingga setiap orang dapat menemukan ekspresi budaya tradisional yang terdapat di negara masing-masing. Di lain pihak, akses terhadap semua pihak yang berkepentingan harus tetap dibuka dengan memperhatikan keamanan penggunaannya oleh masyarakat yang bukan berasal dari komunitas ekspresi budaya tradisional. Dalam rangka perlindungan ekspresi budaya tradisional, UNESCO bekerja sama dengan WIPO selain mengembangkan kerja sama antarorganisasi, UNESCO merekomendasikan agar setiap anggotanya bekerja sama dengan asosiasi internasional maupun regional dalam hal perlindungan, pelestarian, pendokumentasian, dan penyebaran ekspresi budaya tradisional. Secara keseluruhan terdapat kesamaan tujuan dan objek perlindungan dalam Hukum Nasional dan Hukum Internasional, walaupun masih ada beberapa ketidaksamaan dalam hal penentuan ruang lingkup dan definisi atas ekspresi budaya tradisional. Namun demikian, isi konvensi internasional dapat dijadikan pedoman dalam rangka pemenuhan hak-hak masyarakat tradisional atas ekspresi budaya tradisional dan memperkuat pengaturan ekspresi budaya tradisional dalam sistem sui generis. 


\section{DAFTAR PUSTAKA}

\section{Buku}

Badan Penelitian dan Pengembangan HAM Kementerian Hukum dan HAM RI. Perlindungan Kekayaan Intelektual Atas Pengetahuan Tradsional dan Ekspresi Budaya Tradisional Masyarakat Adat, Bandung: Alumni, 2013.

Damian, Eddy. Glosarium Hak Cipta dan Hak Terkait. Bandung: Alumni, 2012.

Hadikusuma, Hilman. Pengantar Hukum Adat. Jakarta: Mandar Maju, 2010.

Janke, Terri. Our Culture: Our Future-Report on Australian Indigenous Cultural and Intellectual Property Rights. Sydney: Michael Frankel and Company, 1999.

Jened, Rahmi. Hukum Hak Cipta (Copyright Law). Bandung: Citra Aditya Bakti, 2014.

Kusumadara, Afifah. Analysis of The Failure of The Implementation of Intellectual Property Laws in Indonesia, A dissertation submitted in fulfillment of the requirements for the degree of Doctor of Juridical Studies, Faculty of Law University of Sydney, 2000.

Lidsey, Tim dkk. Hak Kekayaan Intelektual Suatu Pengantar. Bandung: Alumni, 2002.

Lutviansori,Arif. Hak Cipta dan Perlindungan Folklor di Indonesia. Yogyakarta: Graha Ilmu, 2010.
Purba, Afrillyana. TRIPS- WTO dan Hukum Hak Kekayaan Intelektual Indonesia Kajian Perlindungan Hak Cipta Seni Batik Tradisional. Jakarta: Rineka Cipta, 2005.

Rato, Dominikus. Pengantar Hukum Adat. Surabaya: LaksBang Pressindo, 2009. Roisah, Kholish. Konsep Hukum Hak Kekayaan Intelektual Sejarah, Pengertian, dan Filosofi Pengakuan HKI dari Masa ke Masa. Malang: Setara Press, 2015.

Sulistiyono, Adi. Mekanisme Penyelesaian Sengketa HaKI (Hak atas Kekayaan Intelektual). Solo: Sebelas Maret University Press, 2004.

Susanti, Diah Imaningrum dkk, Ekspresi Budaya Tradisional dan Hak Kekayaan Intelektual, Malang: Dioma, 2019.

World Intellectual Property Organization, Consolidated Analysis of the Legal Protectiona of Traditional Cultural Expression/ Expression of Folklore, Background Paper I, 2003.

\section{Jurnal}

Adanda, Pamela. "Striking a Balance between Intellectual Property Protection of Traditional Knowledge, Cultural Preservation and Access to Knowledge". Journal of Intellectual Property Rights Vol. 17, (November 2012). 
Antons, Christoph. "What is "Traditional Cultural Expression?, International Definitions And Their Application in Developing Asia”, WIPO Journal, Vol. 1, Number. 1, (2009): 103-116.

Atsar, Abdul. "Perlindungan Hukum Terhadap Pengetahuan dan Ekspresi Budaya Tradisional Untuk Meningkatkan Kesejahteraan Masyarakat Ditinjau Dari Undang-Undang Nomor 5 Tahun 2017 tentang Pemajuan Kebudayaan dan Undang-Undang Nomor 28 Tahun 2014 tentang Hak Cipta”, Jurnal Law Reform Vol. 13, No. 2, (September 2017).

Aulia, M. Zulfa. "Perlindungan Hukum Ekspresi Kreatif Manusia: Telaah Terhadap Perlindungan Hak Kekayaan Intelektual Dan Ekspresi Budaya Tradisional”. Jurnal Hukum No. 3, Vol.14, (Juli 2007).

Bhat, P. Ishwara. " Protection of Cultural Property Under International Humanitarian Law: Some Emerging Trends". ISIL Year Book of International Humanitarian and Refugee Law, (2001).

Fischer, Susanna Frederick. "Dick Whittington And Creativity: From Trade To Folklore, From Folklore To Trade", Symposium "The Power of Stories: Intersections of Law, Literature, and Culture The Dick Whittington Story: Its Influences \& Its Impacts, 12 Tex. Wesleyan L. Rev. 5, Texas Wesleyan Law Review, Fall 2005, p. 20.
Husamah. "Mengusung Kembali Khazanah Identitas Budaya Bangsa”. Jurnal Bestari Vol 42, (2009).

Kartika, Eva Dewi. "Perlindungan Hukum atas Cerita Rakyat yang Ditulis oleh Pencipta Dalam Rangka Benefit Sharing”. Jurnal Hukum \& Pembangunan Vol.48, No. 2, (April-Juni 2018).

Kusumadara, Afifah. "Pemeliharaan dan Pelestarian Pengetahuan Tradisional dan Ekspresi Budaya Tradisional Indonesia: Perlindungan Hak Kekayaan Intelektual dan Non-Hak Kekayaan Intelektual". Jurnal Hukum Vol 18, No.1, (2011).

Lewinski, Silke von. "The Protection Of Folklore", 11 Cardozo J. Int'l \& Comp. L. 747, Cardozo Journal of International and Comparative Law, Summer 2003.

Melianti, Yusna dkk. "Pengaturan Folklor Secara Sui Generis Dalam Undangundang Tersendiri”. Masalah - Masalah Hukum Jilid 45 No. 1, (Januari 2016).

Oseitutu J.J., "A sui generis regime for traditional knowledge; the cultural divide in intellectual property law", The Marquette Intellectual Property Law Review Vol. 15, No. 1, (2011).

Philips, Jake. “Australia's Heritage Protection Act : An Alternative to Copyright in the Struggle to Protect Communal Interests in Authored Works of Folklore". Pacific Rim and Policy Journal 18 Pac. Rim L. \& Pol'y J. 547, (August 2009). 
Purnamasari, Wulan Anggie. "Penyelesaian Sengketa Perselisihan Tradisional dan Ekspresi Budaya Antar Negara : Sengketa Lagu Rasa Sayange Antara Negara Indonesia dan Negara Malaysia". Jurnal Hukum dan Pembangunan Vol. 45 No. 4, (OktoberDesember 2015).

Rafianti, Laina dan Qoliqina Zolla Sabrina. "Perlindungan bagi 'Kustodian' Ekspresi Budaya Tradisional Nadran Menurut Hukum Internasional dan Implementasinya dalam Hukum Hak Kekayaan Intelektual di Indonesia”. Padjajaran Jurnal Ilmu Hukum Vol. 1, No. 3, (2014).

Rane, Meghana Rao. "Aiming Straight: The Use of Indigenous Customary Lawto Protect Traditional Cultural Expressions". Pacific Rim Law \& Policy Journal Vol. 15 No. 3.

Septarina, Muthia. "Perlindungan Hukum Pengetahuan Tradisional Dalam Konsep Hukum Kekayaan Intelektual”. Al'Adl Vol. VIII, No. 2, (Mei-Agustus 2016).

Setyaningtyas, Ayu Citra dan Endang Sri Kawuryan. "Menjaga Ekspresi Budaya Tradisional di Indonesia”. Jurnal Ilmu Hukum Tambun Bungau Vol. 1, No. 2, (September 2016).

Spangler, Stephanie. "When Indigenous Communities Go Digital : Protecting Traditional Cultural Expressions Through Integration of IP and
Customary Law". 27 Cardozo Arts \& Ent.L.J.709., Cardozo Arts and Entertainment Law Journal, 2010.

Stoianoff, Natalie and Alpana Roy. "Indigenous Knowledge and Culture in Australia-The Case for Sui Generis Legislation". Monash University Law Review 745, (2015).

Torsen, Molly. "Intellectual Property And Traditional Cultural Expressions: A Synopsis Of Current Issues", 3 Intercultural Hum. Rts. L. Rev. 199, Intercultural Human Rights Law Review, (2008): 203.

Ying, Kuek Chee. "Protection of Expressions of Folklore/ Traditional Cultural Expressions: To What Extent is Copyright Law the Solution?". Journal of Malaysian and Comparative Law $3 / 17 / 2011$

\section{Website}

Burri, Mira. "Digital Technologies and Traditional Cultural Expressions: A Positive Look at a Difficultt Relationship, International Journal of Cultural Property". www.researchgate. net. Accessed 6 October 2009

Sofia, Maya dan Tasya Paramita. "Upaya Pemerintah agar Budaya Indonesia Tak Diklaim Negara Lain”. www.life. viva,co,id .

Overview Intellectual Property and Genetic Resources, Traditional Knowledge and Traditional Cultural Expressions, World 
Intellectual Property Organization (WIPO), 2015, www.wipo.int.

Samoa Law Reform Commision, The Protection of Samoa's Traditional Knowledge and Expressions of Culture, Issues Paper IP 08/10, June 2010.

Statistik Kebudayaan 2019, www.publikasi. data.kemdikbud.go.id.

Update Indonesia, Volume V, No. 6- Oktober 2010, Menelusuri Konflik IndonesiaMalaysia, www.theindonesiainstitute. com.

World Intellectual Property Organization, Consolidated Analysis of the Legal Protectiona of Traditional Cultural Expression/ Expression of Folklore, Background Paper I, 2003. WIPO/ GRTKF/IC/19/INF/7 ('Glossary of Key Terms Related to Intellectual Property and Traditional Cultural Expressions'), www.wipo.int.

WIPO/GRTKF/IC/19/INF/8 ('Glossary of Key Terms Related to Intellectual Property and Traditional Knowledge'), www.wipo.int.

WIPO/GRTKF/IC/19/INF/9 ('Glossary of Key Terms Related to Intellectual Property and Genetic Resources'), www.wipo.int.
WIPO Revised Objectives and Principles for the Protection of Traditional Cultural Expressions and Expressions of Folklore, www.wipo.int.

\section{Peraturan Perundang-undangan}

Undang-undang Nomor 28 Tahun 2014 tentang Hak Cipta

Rancangan Undang-undang Pengetahuan Tradisional dan Ekspresi Budaya Tradisional

Intergovernmental Committee on intellectual Property and Genetic Resources, Traditional Knowledge and Folklore

Trade Related aspect of Intellectual Property Rights Agreement

Convention on the Protection and Promotion of theDiversity of Cultural Expression 2005 Convention for the Safeguarding of the Intangible Cultural Heritage 2003

The South Pacific Model Law for National Laws of 2002

Model Provisions of the UNESCO/WIPO 1982

The Tunis Model Law on Copyright for Developing Countries of 1976

The Berne Convention for the Protection of Literary and Artistic Work (as amended on September 28, 1979) 